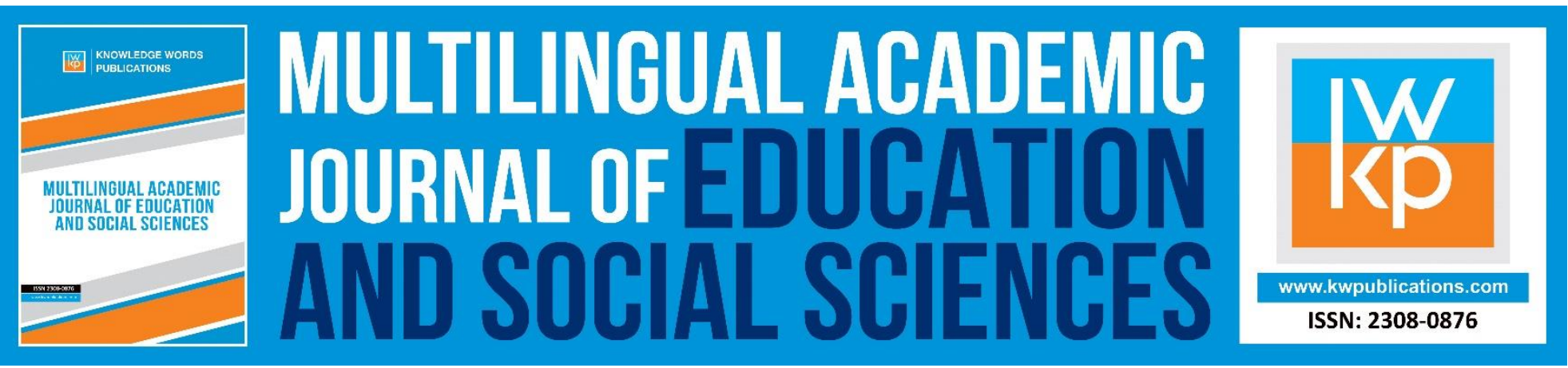

\title{
Peer Feedback: Its Impact on Assessing Writing in Greek as a Second Language
}

\section{Alexandra Anastasiadou, Konstantina lliopoulou}

To Link this Article: http://dx.doi.org/10.46886/MAJESS/v5-i1/2426

DOI: 10.46886/MAJESS/v5-i1/2426

Received: 03 June 2017, Revised: 24 July 2017, Accepted: 07 September 2017

Published Online: 20 October 2017

In-Text Citation: (Anastasiadou \& Iliopoulou, 2017)

To Cite this Article: Anastasiadou, A., \& Iliopoulou, K. (2017). Peer feedback: Its Impact on Assessing Writing in Greek as a Second Language. Multilingual Academic Journal of Education and Social Sciences, 5(1), 14-28.

Copyright: ( ) The Authors 2017

Published by Knowledge Words Publications (www.kwpublications.com)

This article is published under the Creative Commons Attribution (CC BY 4.0) license. Anyone may reproduce, distribute, translate and create derivative works of this article (for both commercial and non-commercial purposes), subject to full attribution to the original publication and authors. The full terms of this license may be seen at: http://creativecommons.org/licences/by/4.0/legalcode

Vol. 5, No. 1, 2017, Pg. 14 - 28

https://kwpublications.com/journals/journaldetail/MAJESS

Full Terms \& Conditions of access and use can be found at https://kwpublications.com/pages/detail/publication-ethics 


\title{
Peer Feedback: Its Impact on Assessing Writing in Greek as a Second Language
}

\author{
Alexandra Anastasiadou \\ Directorate of Education for Central Macedonia, Greece, Dissertation Supervisor at the Hellenic \\ Open University \\ Email: dhm3kat@yahoo.gr
}

Konstantina lliopoulou

Experimental School of Aristotle University of Thessaloniki, Lecturer at Nicosia University Greek Language Center

Email: k.iliopoulou@yahoo.gr

\begin{abstract}
Peer feedback has gathered momentum in writing courses in the last twenty years, since it contributes to the improvement of the students' writing skills, their motivation and collaboration. To this end, the present study aimed at investigating the effectiveness of peer review from a cognitive and attitudinal perspective within the framework of the "process writing" approach to teaching writing in the context of teaching Greek as a second language. Elements of the genre approach were also incorporated in the "process writing" framework. More specifically, a study was carried out in the second grade of a Greek Intercultural Junior high school involving twenty students of diverse nationalities. The subjects attended six writing lessons whereby they were provided with peer commentary. Pre- and post-questionnaires were administered to the participants to identify their attitudes towards peer feedback at the entry point of the research and trace any differentiation in their stances at the exit point of the intervention. The findings revealed a positive shift of the respondents' attitudes towards the merits of peer treatment and unraveled development of their metacognitive awareness in that they gained insight in their writing development in Greek as a SL.
\end{abstract}

Keywords: Peer Feedback, Process Writing, Genre Approach, Writing in Greek as a SI/FI, Fostering Favorable Stances Towards Peer Collaboration In Assessment.

\section{Introduction}

In Krashen's $(1982,1985)$ theory of Second Language Acquisition the "Affective Filter Hypothesis" represents a basic prerequisite which facilitates learning. According to this hypothesis, the 
MULTILINGUAL ACADEMIC JOURNAL OF EDUCATION AND SOCIAL SCIENCES

Vol. 5 No. 1, 2017, E-ISSN: 2308-0876 @ 2017 KWP

affective filter is an imaginary emotional barrier preventing learners from fully assimilating the second language input. An effective method of lowering this affective filter is to ensure optimal conditions in the classroom which can maximize learning through communication and collaboration. Peer cooperation through mutual feedback is an ideal way of securing an unthreatening learning environment in the classroom. Furthermore, peer commentary enables writing teachers to assist their students to receive more feedback on their writing as well as offer students practice in a variety of skills which are deemed important in developing language and their writing dexterity, such as purposeful interaction with fellow students, greater experimentation with ideas, and new interpretation of the writing procedure. Peer evaluation has assumed a pivotal role in both first (L1) and second language (L2) writing classrooms "based on theories in collaborative learning and social cognitive development" (Coit, 2004, p. 902).

In the present research, the implementation of peer commentary has been probed within the process-writing approach as various studies have confirmed that peer feedback is best achieved in the process-writing framework (Al-Jamal, 2009; Ting \& Qian, 2010; Farrah, 2012; Anastasiadou, 2015). The process-writing pedagogy emerged as an opposition to the prevailing paradigms to teaching writing which overemphasized the product of writing in the form of a predetermined structure. Rather than repudiate concern with the final product, though, the process approach, aims at attaining the best final product possible by enabling the students to draft and redraft their text in an effort to improve it. Peer feedback can be best exploited in this multiple drafting stage. In an attempt to supplement the process pedagogy, various theorists (Hedge, 1988; White \& Arndt, 1991) incorporated other significant dimensions, namely the purpose and context of writing, the target audience, and cooperation among the students during composing and revising, and between the students and the teacher embedding, thus, the interactive and social parameters in writing. Finally, White \& Arndt (1991) unearthed the significance of providing students with ample practice in experimenting with the characteristics of various text types. Consequently, the process approach incorporated vital elements of the genre approach which maintains that the text types vary according to the social context in which they are produced (Cope \& Kalantzis, 1993). Going a step further, Badger \& White (2000) introduced the process genre approach as a hybrid paradigm whereby the constituents of the two pedagogies are interwoven. In this light, the first researcher formulated a process writing framework which embeds elements of the genre approach. This schematic representation is cyclical and affords the possibility of a complex, intermingling of the various stages (figure 1).

The student takes into account the activity requirements which entail the target reader, the generic type of the text, its topic and aim and the social milieu in which the specific text is formulated. The teacher is also associated with these traits with a view to assisting the learners to comprehend and successfully utilise them. Moreover, these characteristics determine the produced text. The requirements of the activity initiate the process of writing which is recursive allowing, thus, the writer to revisit previous stages in order to remedy them. This circular procedure is reciprocally interrelated to the text, in that it initiates the text and the final product feeds this procedure. The teacher and the students cooperate in the shared endeavour of identifying the writing phases and finalising the text. Much in the same vein, the students interact with their peers in performing group tasks and providing each other with formative feedback. 
MULTILINGUAL ACADEMIC JOURNAL OF EDUCATION AND SOCIAL SCIENCES

Vol. 5 No. 1, 2017, E-ISSN: 2308-0876 @ 2017 KWP

\section{Literature Review}

The value of peer response in the second/foreign language writing classroom has been greatly acknowledged by various theorists (Lee, 1997; Frankenberg-Garcia, 1999; O' Brien, 1999). It can contribute to the development of learning and increase student motivation (Hyland \& Hyland, 2006) and at the same time it enables students to identify the weak and strong points in their writing and, thus, improve their writing proficiency (Cai, 2011). Moreover, through peer review students are assigned the role of a teacher (Liu \& Hansen, 2002) and, in this sense, they are actively engaged in their own learning and assume responsibility of their own learning progress.

In this light, many studies have investigated the potential of peer feedback. In an attempt to explore a new way for combining assessment and knowledge in the framework of a hybrid online learning methodology in a postgraduate course, Barak

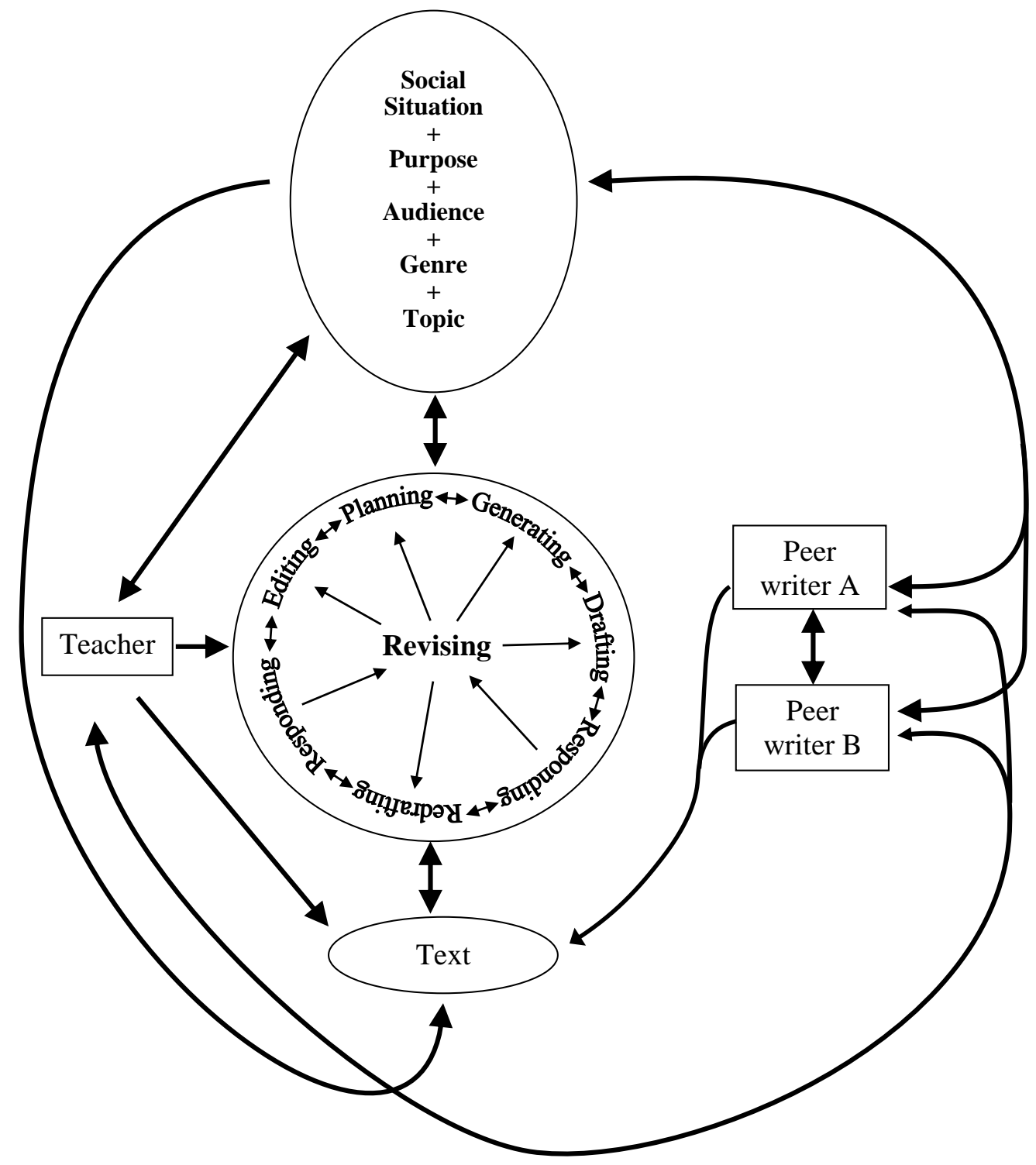

Figure 1. Process writing framework incorporating vital components of the genre approach Based on Anastasiadou (2011) 
MULTILINGUAL ACADEMIC JOURNAL OF EDUCATION AND SOCIAL SCIENCES

Vol. 5 No. 1, 2017, E-ISSN: 2308-0876 @ 2017 KWP

\& Rafaeli (2004) reported that the students who received constructive criticism via peer review displayed a positive stance towards it and improved their performance by attaining higher scores in the final examination. Likewise, working in a tertiary context in an undergraduate course, though, Cho, Schunn \& Charney (2006) concluded that participants rated the peer commentary as interesting and time worthy. Moreover, they granted more value to rewarding comments which praised the strengths of their pieces of writing. Similarly, having implemented peer assessment with university students Berg, Admiraal and Pilot (2006) highlighted the supremacy of feedback on the participants' drafts during the writing process as compared to peer response to the final product. They recommended the employment of peer commentary in small groups and claimed that a combination of oral and written treatment translates into better results, since oral response resulted in improvement in style, whereas written review focused mainly on structure.

Zundert et al. (2010) concluded that the employment of peer review not only ameliorates students' writing competence but it also favourably influences their stances regarding peer collaboration during writing through exposure to adequate training and ample practice. Kaufman and Shunn (2011), examining learners' perceptions regarding peer correction, unfolded data which contradict the ones of previous studies. More specifically, the participants echoed their disbelief in the fairness of peer review and questioned the ability of their fellow students to assess their writing as they lack the necessary qualifications. A striking finding of this study, though, was that this partly negative attitude towards peer review reliability did not appear to influence the extent of the participants' revision. Therefore, the researchers conclude that be it negative or positive, the learners' perceptions of peer assessment does not seem to affect their revision work. Azarnoosh (2013) investigated a very interesting aspect of peer assessment, that is any possible student partiality due to friendship prejudice. Contrary to previous research which had traced familiarity bias in peer review (Falchikov, 1995; Morahan-Martin, 1996), the present researcher did not detect any significant variation between the responses of friend and nonfriend pairs. Moreover, results pointed to the fact that the students showed positive attitudes towards peer review ranking it as beneficial, challenging and interesting.

A last study conducted in the primary school context (Anastasiadou, 2015) attempted to gauge the students' notions towards peer reinforcement and measure the impact of this peer collaboration on the learners' performance. The findings highlighted that, while the learners were opposed to receiving commentary on their writing in the beginning of the research, they were favourably disposed towards peer review in the end of the intervention which involved seven writing lessons. An additional finding of the present research was the students' positive reaction towards receiving treatment on the weak points of their texts opposing their reluctance in the beginning of the intervention. Moreover, the learners welcomed the provision of a correction code by the teacher in order to rectify their own and their partners' errors, a practice which had been unfamiliar to them before the intervention. Another significant finding was that the subjects rated the whole process as interesting and time worthy. Finally, there was a statistically significant improvement of the participants' writing competence pinpointing the salience of student interaction in the assessment process.

Even though a host of studies have been carried out regarding peer feedback in the context of teaching English as a foreign/second language, little research has been conducted concerning teaching writing in Greek as a second/foreign language. Given the research gap in this 
MULTILINGUAL ACADEMIC JOURNAL OF EDUCATION AND SOCIAL SCIENCES

Vol. 5 No. 1, 2017, E-ISSN: 2308-0876 C 2017 KWP

setting, the present researchers ventured this study with the aim of identifying the learners' stances towards the profits of peer review in the Greek ESL/EFL writing classroom.

\section{The Purpose of the Study}

Taking into account the importance of peer reinforcement during the writing process and its influence on developing the students' metacognitive awareness towards appropriate practices which can ameliorate their writing proficiency, the following research questions were articulated:

(1) Can peer-assessment aid learners to gain insight into their own learning progress and writing skill development?

(2) Do the students who receive peer feedback to teaching writing in the second language classroom acknowledge its benefits?

\section{Methodology}

The intervention was implemented in the second grade of a Greek Intercultural junior high school which is a kind of school mainly attended by repatriots and migrant students, whereby Greek is taught as a second language. The instructor was trained by the researchers and one of the researchers was present during the writing sessions in order to monitor the progress of the whole procedure.

\section{Participants}

The subjects were 20 students enrolled in the 2 nd grade having finished the 1 st-year introductory cycle according to their level. The sample consisted of 14 boys and 6 girls, ranging from 14 to 16 years old. The countries of their origins were Georgia, Albania, Afganistan, China, New Guinea and Russia.

\section{Instrumentation}

The employed instruments were the following A pre- and post-questionnaire was given to students with a view to tracing their opinions in relation to peer response to their written texts in the entry and exit point of the research and identify any differentiation due to the intervention. A correction code was designed by the first researcher (appendix I) containing symbols along with their meaning and examples with the aim of aiding the students to detect their mistakes. Finally, the subjects attended six writing lessons whereby they applied peer response.

\section{Procedure}

\section{Pre-questionnaire}

The initial questionnaire was divided into three parts, as follows:

Part one involved personal questions regarding participants' age, sex, country of origin, part two included seven items concerning aspects of partners' responses and part three consisted of 10 statements related to more general parameters of the applied alternative assessment, that is peer assessment. Closed-ended items were used as they are easy to answer, code and analyse (Dörnyei , 2003, p. 35) employing a 3-point Likert scale. 
MULTILINGUAL ACADEMIC JOURNAL OF EDUCATION AND SOCIAL SCIENCES

Vol. 5 No. 1, 2017, E-ISSN: 2308-0876 @ 2017 KWP

\section{The Correction Codes}

Following Jacobs et al.'s (1981) typology for evaluating second language writing, the first researcher formulated the correction code based on specific criteria in order to ensure clarity in the assessment and facilitate the learners to mark their fellow students' deficiencies and good points. The following criteria were employed: 1. Content, 2. Organisation, 3. Vocabulary, 4. Language Use, 5. Mechanics.

A special session was devoted to familiarise participants with the use of the code through two texts. In this lesson the learners were required to spot the errors in the texts and highlight them so as to be prepared to employ the same procedure in the following lessons whereby they would be requested to rectify their partners' texts.

\section{Writing Lessons}

Six writing lessons were conducted following the process genre approach. Concerning the generic type of the text under examination in every writing lesson, a progressive text difficulty was chosen in each successive lesson. Moreover, complying with White \& Arndt's (1991) advice, selective error treatment was applied to avoid overwhelming learners with excessive feedback which might confuse or dishearten them. Additionally, the students' good points were raised in order to aid them recognize their progress and attract their interest in getting involved in writing (Hedge, 1988). Thus, the following framework was followed with regard to the topic to be dealt with, the text type to be produced and the kind of errors to be treated in each session (Table 1):

Table 1: The writing context

\begin{tabular}{llll}
\hline Week & Genre & Topic & Criterion \\
\hline 1st & Paragraph & My school & Content \\
2nd & Diary & The benefits of friendship & Organization \\
3rd & Personal letter & My mother in hospital & Vocabulary \\
4th & Formal letter & TV producer about adverts & Language use \\
5th & Speech & On-line games & Mechanics \\
6th & Article & Unemployment & All the above \\
\hline
\end{tabular}

In each lesson, the students were asked to experiment with the features of a different discourse type. They cooperated in an attempt to find the traits of each genre performing various tasks. These activities included examining a similar text type, comparing a well-written and a badly-written text, brainstorming the correct layout of a piece of writing, exploiting a picture or a sequence of pictures, to mention but a few. Then, the participants were requested to produce a text of the same genre on a certain topic, for a specific purpose, audience and social situation.

The first draft was produced, interchanged in dyads and evaluated by the partners by means of underlining the defects following the error code. Having received this type of peer response, the students were, then, asked to rewrite as homework their text abiding by their partners' comments with the aim of preparing their second draft. This second draft was evaluated again in the next lesson by the same peers who had provided feedback on the students' first draft. The learners corrected the second draft creating the final product of their writing which was handed in to the teacher to be evaluated. 
MULTILINGUAL ACADEMIC JOURNAL OF EDUCATION AND SOCIAL SCIENCES

Vol. 5 No. 1, 2017, E-ISSN: 2308-0876 @ 2017 KWP

\section{The Post-questionnaire}

The post-questionnaire was worded similarly to the entry questionnaire in order to offer the possibility to compare the subjects' beliefs in relation to peer commentary in the beginning and the end of the intervention, and at the same time provide insight into any opinion variation or lack thereof.

\section{Analysis of the Data}

The quantitative analysis of the results was conducted by means of measuring and comparing the subjects' responses to the items of the pre- and post-questionnaire on a percentage scale gauging the frequency and percentages of the answers. The main target was to monitor the respondents' ability to meditate on the potential of peer feedback to enhance their writing progress.

\section{Findings and Interpretation}

This section presents and interprets the results of the study in an attempt to discover whether the research questions were verified, to search for ostensible explanations and discuss the pedagogical implications of the accrued data.

At the entry point, an overwhelming majority of the participants (80\%) were unfavourably disposed to the statement "I improve when my peer provides feedback on the content of my writing (such as ideas, examples, etc)". At the exit point, nevertheless, $75 \%$ endorsed the salience of collaboration with their partners concerning the content of their writing compared to $10 \%$ who expressed disagreement with the item under question, while $15 \%$ were undecided (Figure 1).

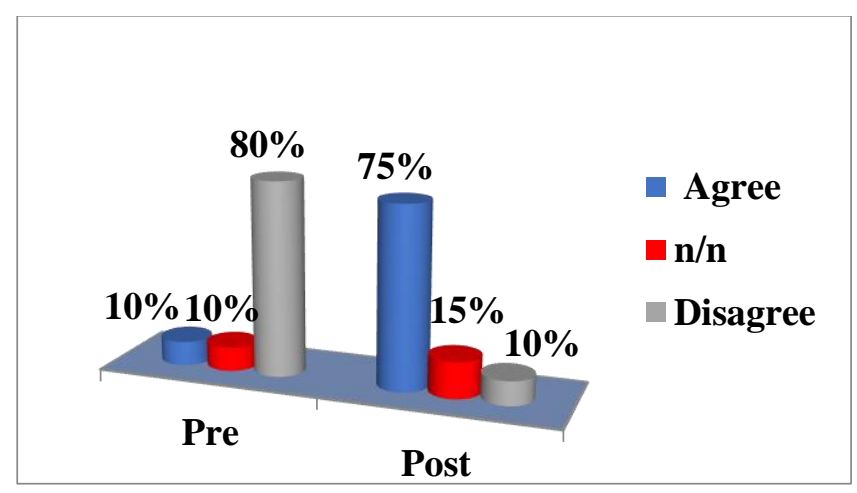

Figure 1: I improve when my peer provides feedback on the content of my writing

With regard to the second question that sought to explore the possible writing amelioration triggered by peer comments on the organization of the text, the analysis of the answers revealed the following results: before the intervention most students (70\%) stated that they do not improve when their peer comments on the organization of their texts (such as sequencing, logical development, etc). After the intervention, few subjects retained the original belief that that their writing is not enchanced $(10 \%)$, whereas three quarters of the participants (75\%) exhibited positive mentality in relation to peer comments on the organization of their text. $15 \%$ of them retained a neutral opinion (Figure 2 ). 
MULTILINGUAL ACADEMIC JOURNAL OF EDUCATION AND SOCIAL SCIENCES

Vol. 5 No. 1, 2017, E-ISSN: 2308-0876 @ 2017 KWP

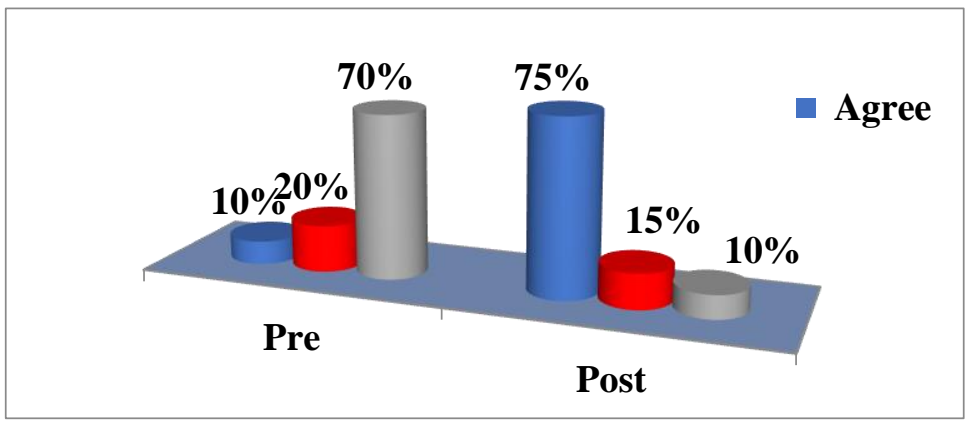

Figure 2: I improve when my peer provides feedback on the organisation of my text.

A striking finding surfaced in the third item whereby the respondents' beliefs were diametrically opposite in the entry and exit point of the research. More specifically, before the intervention $65 \%$ disagreed, $20 \%$ were undecided and only $15 \%$ agreed about the contribution of their partner to the development of their vocabulary. At the end, $75 \%$ acknowledged the contribution of peer review to vocabulary enhancement, $10 \%$ were opposed and $15 \%$ expressed a neutral opinion (Figure 3).

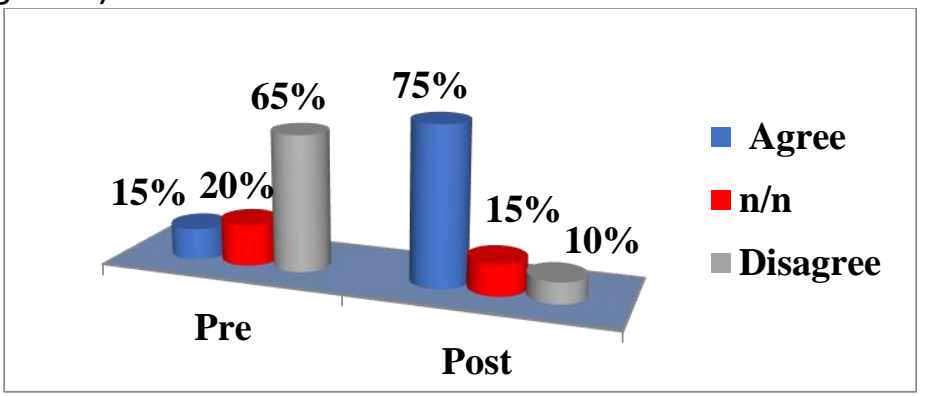

Figure 3: I improve when my peer provides feedback on my vocabulary (i.e. using words accurately)

The vast majority of the participants (80\%) disapproved of the contribution of their partners' attempt to mark their mechanical mistakes at the entry point, while in the end the peer assessment on mechanical mistakes was granted a high percentage of agreement (75\%). 15\% remained undecided and only 5\% - compared to the initial 15\%-expressed their dissent to this particular item (Figure 4).

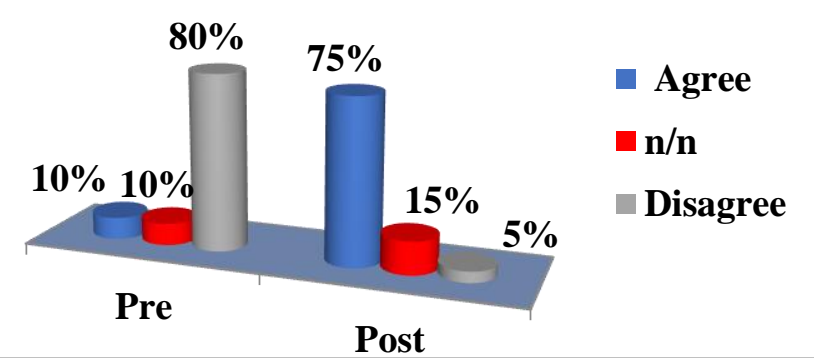

Figure 4: I improve when my peer marks mechanical mistakes (i.e. spelling, punctuation)

The fifth item referred to peer response to the partner's writing style. The results 


\section{MULTILINGUAL ACADEMIC JOURNAL OF EDUCATION AND SOCIAL SCIENCES}

Vol. 5 No. 1, 2017, E-ISSN: 2308-0876 @ 2017 KWP

indicated significant variations in the students' perspectives towards receiving peer response on this issue prior to and after the study. As shown in Figure 5, the students expressed remarkably more assent in the post-questionnaire (70\%) as compared with the pre-questionnaire (10\%). The percentage of $20 \%$ who refused to express either a positive or a negative opinion at the entry point was reduced to $15 \%$ at the exit point.

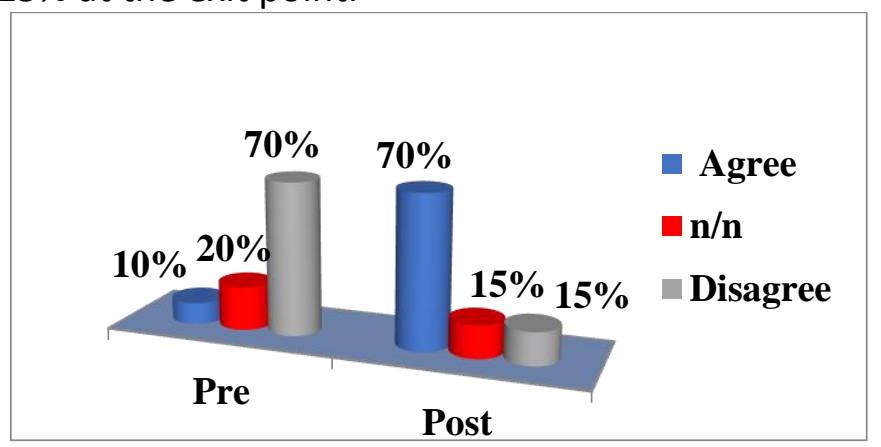

Figure 5: I improve when my peer provides feedback on my writing style (i.e. formal/informal tone)

The most striking finding was that none of the participants attributed credit to receiving feedback by means of a correction code in the beginning of the study. On the contrary, after the intervention they highly endorsed (70\%) the beneficial effect of the use of a correction code on their writing while, those who could not decide were decreased to 15\% (Figure 6).

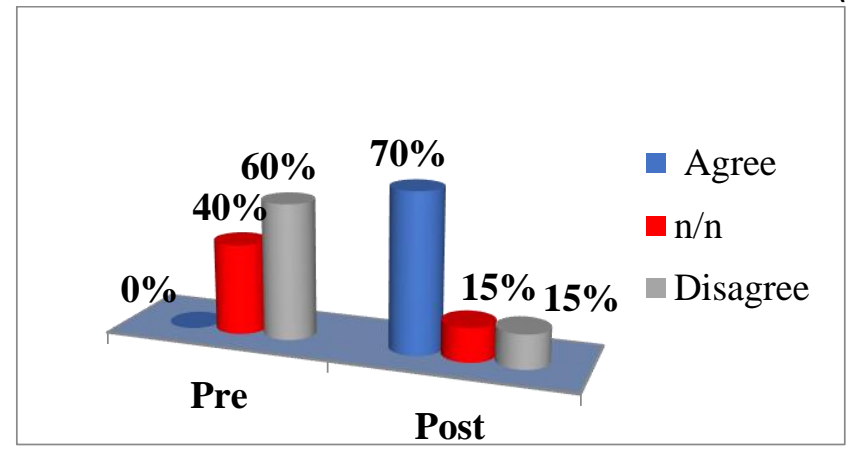

Figure 6: I improve when my peer identifies errors with correction symbols

The most significant alterations in opinions arose in the participants' answers to the item "I improve when my peer underlines errors with a red pen". Although $90 \%$ of the respondents indicated disapproval of having their mistakes underlined in red, most of them (70\%) appeared to adopt a quite different attitude compared to their primary one, as is illustrated in the following figure (Figure 7 ). $20 \%$ of them were undecided and only $10 \%$ retained their initial aversion. 
MULTILINGUAL ACADEMIC JOURNAL OF EDUCATION AND SOCIAL SCIENCES

Vol. 5 No. 1, 2017, E-ISSN: 2308-0876 @ 2017 KWP

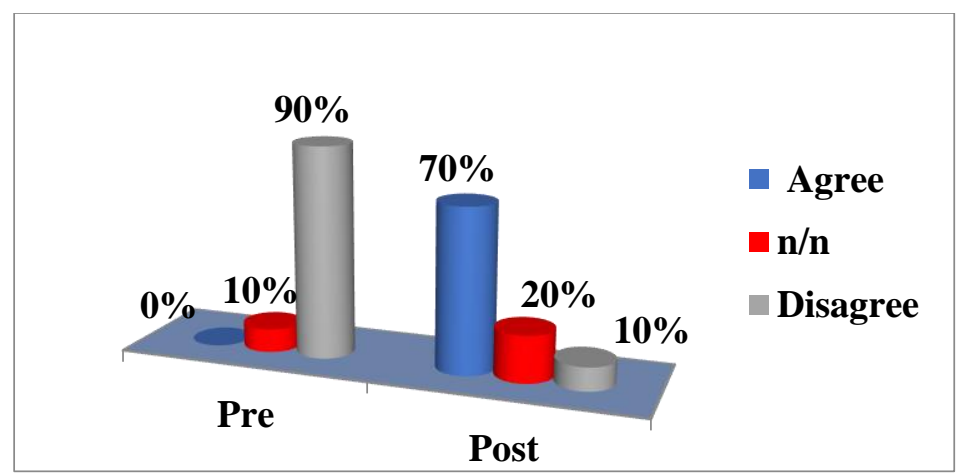

Figure 7: I improve when my peer underlines errors with a red pen

Having analyzed the students' attitudes regarding specific aspects of peer review, table 2 will present their opinions concerning peer treatment as a whole involving the ten last items of the questionnaire.

Table 2: The learners' attitudes towards providing and receiving feedback in writing

\begin{tabular}{|c|c|c|c|c|c|c|c|}
\hline \multirow[t]{2}{*}{$n / n$} & \multirow[t]{2}{*}{ Statements } & \multicolumn{3}{|l|}{ Pre- } & \multicolumn{3}{|l|}{ Post- } \\
\hline & & Disagree & $n / n$ & Agree & Disagree & $n / n$ & Agree \\
\hline 1. & $\begin{array}{l}\text { I want to receive peer assessment } \\
\text { on the weak points of my writing }\end{array}$ & $90 \%$ & $5 \%$ & $5 \%$ & $15 \%$ & $15 \%$ & $70 \%$ \\
\hline 2. & $\begin{array}{l}\text { I want to receive peer assessment } \\
\text { on the good points of my writing }\end{array}$ & $80 \%$ & $5 \%$ & $15 \%$ & $10 \%$ & $10 \%$ & $80 \%$ \\
\hline 3. & $\begin{array}{l}\text { I enjoy collaboration and } \\
\text { appreciate my peer's contribution } \\
\text { to the correction of my errors }\end{array}$ & $80 \%$ & $15 \%$ & $5 \%$ & $10 \%$ & $20 \%$ & $70 \%$ \\
\hline 4. & $\begin{array}{l}\text { Training on peer assessment } \\
\text { process helps me to provide } \\
\text { comments }\end{array}$ & $5 \%$ & $60 \%$ & $35 \%$ & $0 \%$ & $10 \%$ & $90 \%$ \\
\hline 5. & $\begin{array}{l}\text { Training on peer assessment } \\
\text { process helps me to benefit from } \\
\text { the comments I receive }\end{array}$ & $5 \%$ & $55 \%$ & $40 \%$ & $0 \%$ & $15 \%$ & $85 \%$ \\
\hline 6. & $\begin{array}{l}\text { Peer assessment helps me to pay } \\
\text { more attention to the details of my } \\
\text { own writing }\end{array}$ & $80 \%$ & $10 \%$ & $10 \%$ & $10 \%$ & $10 \%$ & $80 \%$ \\
\hline 7. & $\begin{array}{l}\text { Peer assessment increases my } \\
\text { enthusiasm in writing. }\end{array}$ & $80 \%$ & $10 \%$ & $10 \%$ & $10 \%$ & $15 \%$ & $75 \%$ \\
\hline 8. & $\begin{array}{l}\text { Peer assessment helps me learn } \\
\text { from my own mistakes }\end{array}$ & $70 \%$ & $15 \%$ & $15 \%$ & $10 \%$ & $15 \%$ & $75 \%$ \\
\hline 9. & $\begin{array}{l}\text { Peer assessment helps me to } \\
\text { improve my writing ability as a } \\
\text { whole. }\end{array}$ & $75 \%$ & $20 \%$ & $5 \%$ & $10 \%$ & $10 \%$ & $80 \%$ \\
\hline 10. & $\begin{array}{l}\text { Peer assessment is a boring activity } \\
\text { and waste of time. }\end{array}$ & $5 \%$ & $45 \%$ & $50 \%$ & $85 \%$ & $10 \%$ & $5 \%$ \\
\hline
\end{tabular}

Very little preference was displayed regarding the treatment of both the strengths and weaknesses of their texts in the beginning of the study. At the exit point, though, a beneficial effect was attributed to comments on both their good and weak points at a very high percentage, that is $80 \%$ and $70 \%$ respectively. Moreover, after the intervention $70 \%$ showed eagerness 
MULTILINGUAL ACADEMIC JOURNAL OF EDUCATION AND SOCIAL SCIENCES

Vol. 5 No. 1, 2017, E-ISSN: 2308-0876 @ 2017 KWP

concerning both collaboration in assessment and receiving comments from their fellow students, revealing that most learners realized that the teacher is not the unique provider of feedback. This shift of attitude was striking as a meager $5 \%$ conceded that they valued the effectiveness of peer response in the beginning of the study. Very little endorsement (5\%) was granted to being trained on giving and receiving comments prior to the study, whereas an impressive shift surfaced in the end with very high percentages ( $90 \%$ and $85 \%$ respectively) of the respondents showing preference towards peer assessment training. In addition, most of the participants (80\%, $75 \%$, $75 \%$ and $80 \%$ ) exhibited a highly favourable disposition towards the contribution of peer assessment to the improvement of their writing both at the detail level and as a whole, to the increase of their enthusiasm and to the enhancement of their metacognitive awareness, since they learn to profit from their mistakes. Finally, although half the respondents anticipated that peer assessment would be boring and not worth the time spent on it, after the study the vast majority (85\%) realized that the practice was interesting and time worthy. It can be argued, then, that both research questions were verified as the subjects reflected on ways to improve their writing competence and, simultaneously, they acknowledged the profits of peer assessment in writing in Greek as a second language.

\section{Discussion}

The accrued data advocate and expand the findings of previous studies discussed in section 2. More specifically, the results gathered build on Barak \& Rafeaeli's (2004); Van Zundert et al.'s (2010); Anastasiadou's (2015) studies which revealed that the learners' original negative opposition towards peer collaboration during writing assessment was transformed to a positive disposition at the end of the intervention. The achievement of maximum profits when applying peer review in the drafts rather than the final product emerged in the present research in accordance with earlier findings (Al-Jamal, 2009; Berg, Admiraal \& Pilot, 2010; Ting \& Tang, 2010; Farrah, 2012; Anastasiadou, 2015). Another finding which complies with similar studies (Cho, Schunn \& Charney, 2006; Azarnoosh, 2013; Anastasiadou, 2015) is the fact that the participants ranked peer review as an interesting, challenging practice, well worth devoting classroom time.

The students' preference to receive praising remarks, focusing on the good aspects of their writing is in line with Cho, Schunn \& Charney (2006); Anastasiadou (2015). The most interesting finding of the present study was that the learners granted high value to fellow student comments on their weak points, a finding addressed in very few studies so far, namely Anastasiadou (2015)- to the best of our knowledge.

Finally, a significant finding, which was not sufficiently stressed in other studies, was the willingness of learners of different cultural backgrounds to receive and give advice to their fellow students. This result contradicts Miao, Badger \& Zhen's (2006) assumption that group solidarity in peer assessment may imply tendency to interact with learners of the same rather than a different cultural origin.

\section{Limitations of the Study}

One possible limitation of the present study is the fact that the students were assigned to rewrite their commented on first draft at home. This may mean that parents or siblings may have provided assistance to them, intervening, in this way, in the process. Yet, since the dimension under exploration was the students' attitudes rather than their writing performance, there is very 
MULTILINGUAL ACADEMIC JOURNAL OF EDUCATION AND SOCIAL SCIENCES

Vol. 5 No. 1, 2017, E-ISSN: 2308-0876 @ 2017 KWP

little possibility that any external factors have influenced the results.

\section{Suggestions for Further Research}

Further research could be conducted to investigate the contribution of peer treatment to the participants' writing performance in Greek as a second language. An additional aspect worth monitoring could focus on the accuracy of the comments that the learners offer their peers.

\section{Conclusion}

The present research was carried out with the view to exploring whether the application of peer review and the use of a correction code for remedial work could trigger student reflection on their learning progress and writing development. Moreover, it sought to empower the participants to identify and acknowledge the profits of peer assessment.

It was found that, through the use of peer assessment, the participants gained insight into their own learning process and increased their metacognitive skills being, thus, enabled to monitor their own learning progress. In this sense, the first research question was verified.

Furthermore, the subjects developed favourable attitudes towards peer response within the process-writing context and, as a result, they highly valued its beneficial effects on their eager participation in writing and the improvement of their writing ability in the second language. Thus, the second research question was also substantiated.

It can be argued, then, that even though peer assessment is a time-consuming task, it is an effective teaching practice, which should be incorporated in the second language writing classroom. To this end, training students in the assessment process is a prerequisite. Moreover, special roles could be assigned to students by asking them to set principles for peer assessment and engage them in the selection of criteria for error treatment. In this sense, the learners will develop the sense of text ownership and assume responsibility of their own learning. The learners will not only become critical readers of their writing but they will also develop critical thinking by choosing the right comments for their peers. In this collaborative setting, the students are aided within the Zone of Proximal Development to maximize their writing ability. Finally, their affective filter is lowered, since through peer review they gain the sense of a real audience and, at the same time, they simulate real life learning conditions, as they are requested to interact with their fellow students, which is a practice employed in everyday reality.

\section{References}

Al-Jamal, D. (2009). The impact of peer response in enhancing ninth grader's writing skill. Umm Al-Qura University Journal of Educational \& Psychologic Sciences. Vol. 1-N0. 1 January 2009. (Retrieved October $8^{\text {th }}$ 2012) libback.uqu.edu.sa/.../3200020-8.pdf (Retrieved October 22nd. 2010) http.//uqu. edu.

sa/files2/tiny_mce/plugins/filemanager/files/admins/pag3673/e1. pdf.

Anastasiadou, A. (2011). Implementing the process writing approach in the English language classroom: An innovation for the development of young learners' writing skills in the Greek state primary school. Unpublished doctoral dissertation, Aristotle University of Thessaloniki: Thessaloniki.

Anastasiadou, A. (2015). Feedback revisited: The impact of peer commentary on students' attitudes and writing performance in the EFL classroom. In An-Najah University Journal for 
MULTILINGUAL ACADEMIC JOURNAL OF EDUCATION AND SOCIAL SCIENCES

Vol. 5 No. 1, 2017, E-ISSN: 2308-0876 ๔ 2017 KWP

Research Humanities, Vol. 29/2 ISSN: 1727-8449, ISSN Online: 2311-8962, pp. 369- 402.

Azarnoosh, M. (2013). Peer assessment in an EFL context: Attitudes and friendship bias. Language Testing in Asia. 3(11), 1-10. Available at http://link.springer.com/article/10.1186\%2F22290443-3-11\#page-1.

Badger, R., \& White, G. (2000). "A process genre approach to teaching writing” ELT Journal 54/2, pp.153-160.

Barak, M., \& Rafaeli, S. (2004). On-line question-posing and peer-assessment as a means for webbased knowledge sharing in learning. International Journal of Human-Computer Studies, 61(1), pp. 84-103.

Berg, I., Admiraal, W., \& Pilot, A. (2006). Peer assessment in university teaching: Evaluating seven course designs in Assessment \& Evaluation in Higher Education, 31/1, pp. 19-36.

Cai, J. (2011). A contrastive study of on line peer feedback and online teacher feedback in teaching English writing to college students. Foreign Language World, 134 (2), pp. 65 -72.

Cho, K., Schunn, C. D., \& Charney, D. (2006). Commenting on writing: Typology and perceived helpfulness of comments from novice peer reviewers and subject matter experts. Written Communication, 23(3), 260-294.

Coit, C. (2004). "Peer review in an online college writing course", Proceedings of the IEEE international conference on advanced learning technologies, pp. 902-903.

Cope, B., \& Kalantzis, M. (1993). The Powers of literacy: A Genre approach to teaching writing. Pittsburg: University of Pittsburgh Press.

Dornyei, Z. (2003). Questionnaires in second language research. London: Lawrence Erlbaum Associates, Publishers.

Farrah, M. (2012). "The impact of peer feedback on improving the writing skills among Hebron university students". An-Najah Univ. J. Res. (Humanities). Vol. 26/1 pp. 179-200.

Falchikov, N. (1995). Peer feedback marking: developing peer assessment. Innovations in Education and Training International, 32, pp.175-187.

Frankenberg-Garcia, A. (1999). Providing student writers with pre-text feedback. ELT J 53/2, pp. 100-106.

Hedge, T. (1988). Writing. Oxford: Oxford University Press.

Hyland, K., and Hyland, F. (2006). Feedback in second language writing: Contexts and issues. Cambridge University Press.

Jacobs, H. L., Zingraf, S. A., Wormuth, D. R., Hartfiel, V. F., \& Hughey, J. B. (1981). Testing ESL composition: A practical approach. Rowley, MA: Newbury House.

Kaufman, J., \& Schunn, C. (2010). Students' perceptions about peer assessment for writing: their origin and impact on revision work. Learning Research and Development Center. University of Pittsburgh. Published on line 10 March 2010 at

http://www.Irdc.pitt.edu/schunn/research/

papers/KaufmanSchunnStudentPerceptions.pdf.

Krashen, S. D. (1982). Principles and practice in second language acquisition. Oxford: Pergamon Press.

Krashen, S. D. (1985). The Input Hypothesis: Issues and Implications. London: Longman.

Lee, I. (1997). ESL learners' performance in error correction in writing: Some implications for teaching. System 25/4, pp. 465-477.

Liu, J., \& Hansen, J. (2002). Peer response in second language writing classrooms in Belcher, D. 
MULTILINGUAL ACADEMIC JOURNAL OF EDUCATION AND SOCIAL SCIENCES

Vol. 5 No. 1, 2017, E-ISSN: 2308-0876 @ 2017 KWP

Liu, J. (eds.) Michigan series on teaching multilingual writers. Ann Arbor. MI. University of Michigan Press.

Miao, Y., Badger, R., Zhen, Y. (2006). A comparative study of peer and teacher feedback in a Chinese EFL writing class, Journal of Second Language Writing 15, pp. 179-200.

Morahan-Martin, J. (1996). Should peers' evaluations be used in class projects?: Questions regarding reliability, leniency, and acceptance. Psychological Reports, 78, 1243-1250.

O' Brien, T. (1999). The teaching of writing skills in a second/foreign language. Vol. 3, 4. Patras: Hellenic Open University.

Rollinson, P. (2005). Using peer feedback in the ESL writing class in ELT Journal Volume 59/1 pp. 23-30. doi: 10.1093/elt/cci003.

Steele, V. (2005). "Product and process writing: A comparison" in BBC www.teachingenglish. org.uk/think/think.shtml - 28k - 30.

Ting, M., \& Qian, Y. (2010). "A case study of peer feedback in a Chinese EFL writing classroom". Chinese Journal of Applied Linguistics, Vol. 33/4. Pp. 87-98.

Van Zundert, M., Sluijsmans, D. M. A., \& Van Merrinboer, J. J. G. (2010). Effective peer assessment processes: Research findings and future directions. Learning and Instruction, 20(4), 270279.

White, R., \& Arndt, V. (1991). Process Writing. Harlow: Longman.

\section{About Authors}

Dr Alexandra Anastasiadou, Directorate of Education for Central Macedonia, Greece, Dissertation Supervisor at the Hellenic Open University, dhm3kat@yahoo.gr Dr. Anastasiadou holds a B.A. in English Language and Literature and a B.A. in the Pedagogical Department for Primary Education from Aristotle University, an M.Ed. in TESOL from the Hellenic Open University of Patras, an M.A in Cognitive Development from the Pedagogical Department of Western Macedonia, a Ph.D. in Teaching Writing from Aristotle University and a Post Doc from the University of Western Macedonia. She works as a state school advisor-teacher trainer in the Regional Directorate of Education for Central Macedonia, Greece and as a dissertation supervisor in the postgraduate programme of the Hellenic Open University in Patras. Her research interests include Teaching writing, Teaching young learners, Curriculum design, Teacher Training, Critical literacy, Assessment, CLIL.

Dr Konstantina Iliopoulou, Experimental School of Aristotle University of Thessaloniki, Lecturer at Nicosia University Greek Language Center, k.iliopoulou@yahoo.gr Dr Iliopoulou holds a B.A. in Greek Language and Literature, an M.A. in Theoretical Linguistics and a Ph.D. in Applied Linguistics, from Aristotle University. She works as a Teacher in the Experimental School of Aristotle University and as a lecturer in the postgraduate programme of the University of Nicosia. She has been an external scientific associate of the Centre of Greek Language (Ministry of Education) since 2005. Her research interests include Assessing Greek as an L2, Teaching young learners an L2, Intercultural education, Assessing Writing, Critical literacy, CLIL 